\title{
JUURNAL.RU
}

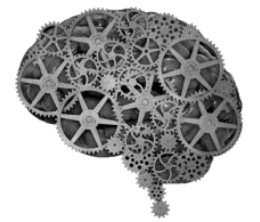

COMPANY GROUP "INTELLEKT"

Куликова К.С. Мордовский государственный университет им. Н.П. Огарева

Саранск, Россия

doi: 10.18411/lj2016-6-2-08

\section{Деформация и модернизация при переводе художественных текстов (на материале повести А.С. Пушкина «Барышня-крестьянка»)}

В 1830 г., в период «Болдинской осени», А.С. Пушкин создал «Повести Белкина». Незамысловатость повествования, простота языка, которым написаны повести, не раз отмечались литературоведами. По мнению Пушкина, язык прозы должен быть точным, простым и естественным. [1] Отказ от специфического стиля Карамзина или так называемого «салонного стиля», особенно ярко проявляется в широком использовании в языке «Повестей Белкина» различных «просторечий».

Обратим особое внимание на повесть «Барышня-крестьянка», в которой, по нашему мнению, наиболее часто употребляется лексика с разговорнодиалектной окраской.

В «Повестях Белкина» просторечие было необходимо как средство характеристики образа. [1] «А по-здешнему я говорить умею прекрасно,»заявила Лиза, тем самым наполнив диалоги повести многочисленными примерами крестьянского наречия.

В своей книге «Из наблюдений над языком «Повестей Белкина», С.И. Абакумов выделяет два типа просторечий:

Разговорно-бытовой язык, компоненты которого общеизвестны, но не приняты в качестве языка книги. 
Социально-областные диалекты, т.е. разговорный язык, элементы которого известны лишь отдельными группам говорящих.

Необходимо отметить, что в тексте повести встречаются в основном элементы разговорно-бытового языка, тем самым упрощая понимание содержания произведения и, соответственно, сам процесс перевода.

В качестве примера рассмотрим перевод, выполненный ДжошемБиллингсом в 2009 году. [2]

\begin{tabular}{|c|c|}
\hline Оригинальный текст [3] & Текст перевода \\
\hline $\begin{array}{c}\text { "Небось, милая,- сказал он Лизе, собака моя не } \\
\text { кусается". Лиза успела уже оправиться от испугу } \\
\text { и умела тотчас воспользоваться обстоятельствами. } \\
\text { "Да нет, барин, - сказала она, притворяясь } \\
\text { полуиспуганной, полузастенчивой, - боюсь: } \\
\text { она,вишь, такая злая; опять кинется""Я провожу } \\
\text { тебя, если ты боишься, -сказал он ей, - ты мне } \\
\text { позволишь идти подле себя?" }\end{array}$ & $\begin{array}{c}\text { “Don'tbeafraid,mydear,” hesaidtoLiza: } \\
\text { “mydogwon'teatyou. “Ohyeah, sir,” she said, } \\
\text { pretending partial shyness, “But I’m scared. See how } \\
\text { mean she is; she’s throwing herself at me again.” } \\
\text { “I’ll come with you if you're afraid,” he told her, «Will } \\
\text { you let me walk beside you?’ }\end{array}$ \\
\hline - "A кmо mе мешаеm? -отвечала Лиза, & “Who’sstoppingyou? \\
\hline - вольному воля, а дорога мирская". - [..] & “Theroad’sforeveryone, followitwhereyoulike.” [...] \\
\hline $\begin{array}{c}\text { "А лжешь, - сказала она, } \\
\text { - не на дуру напал. Вижу, что ты сам барин". }\end{array}$ & $\begin{array}{l}\text { “You'relying,” shesaid. } \\
\text { “I’mnofool.You'retheBarinyourself, I canseeit.” }\end{array}$ \\
\hline $\begin{array}{c}\text { - "Почему же ты так думаешь?" } \\
\text {-"Да по всему". } \\
\text { - "Однако ж?" }\end{array}$ & $\begin{array}{l}\text { "Whatmakesyouthinkthat?” } \\
\text { "Everything, prettymuch.” } \\
\text { "Likewhat?” }\end{array}$ \\
\hline $\begin{array}{c}\text { - "Да как же барина с слугой не распознать? Иодет- } \\
\text { то не так, и башиь иначе, и собаку-то кличешь не } \\
\text { по-нашему". Лиза час от часу более нравилась } \\
\text { Алексею. [...] }\end{array}$ & $\begin{array}{l}\text { “Asif I couldmistake a Barinfor a servant. } \\
\text { Yourclothesarewrong, youspeakdifferent, } \\
\text { youdon’tcallyourdogthewaywedo.” } \\
\text { LizalikedAlexymoreandmoreeveryminute.. [...] }\end{array}$ \\
\hline $\begin{array}{l}\text { Лиза почувствовала,что вышла было из своей } \\
\text { роли, и тотчас поправилась. "А что думаешь? - } \\
\text { сказала она, - разве я и на барском дворе никогда не } \\
\text { бываю? небось: всегонаслышалась и нагляделась. }\end{array}$ & $\begin{array}{l}\text { Liza, who felt that she was straying from her role, } \\
\text { corrected herself. “You really think I’ve never been in } \\
\text { the master’s house?” she asked. “Don’t worry: I’ve } \\
\text { seen and heard everything,” }\end{array}$ \\
\hline $\begin{array}{l}\text { - "И ты не обманешьменя?" } \\
\text { - "Не обману". } \\
\text { - "Побожись". }\end{array}$ & $\begin{array}{l}\text { "You won’t trick me?" } \\
\text { "I won’t trick you." } \\
\text { "Swear." }\end{array}$ \\
\hline "Нувот ме святая пятница, приду". & “By Holy Friday, I’ll come.” \\
\hline $\begin{array}{c}\text { "Ты был, барин, вечор у наших господ? - сказала } \\
\text { онатотчасАлексею, - какова показалась тебе } \\
\text { барышня?" }\end{array}$ & $\begin{array}{c}\text { "You were at the master’s last night, Barin?” she } \\
\text { immediately asked Alexy. "How did you like my } \\
\text { lady?” }\end{array}$ \\
\hline
\end{tabular}

Проанализировав вышеперечисленные примеры, нельзя не отметить однообразность в выборе переводческих стратегий - при передаче разговорнодиалектной лексики на английский язык, переводчик использует приемы деформации и модернизации. 
Применение деформации текста в переводе оказывается прежде всего связанным с категорией переводческой потери, а точнее, с осознанием переводчиком того, что перевод невозможен без различного рода потерь. [4] Поскольку, характерной особенностью данной повести является широкое использование разговорно-диалектной лексики, которая является непереводимой практически в любом художественном тексте, то это еще раз доказывает верность выбора переводческой стратегии.

Как известно, выделяют сознательную и бессознательную деформацию текста. Сознательная деформация проявляется в случае если в текст перевода вносятся какие-либо добавления или, напротив, когда выбрасываются отдельные фрагменты.

Например,

$$
\text { "Нувот те святая пятница, приду". } \quad \text { "By Holy Friday, I'll come." }
$$

Бессознательная трансформация подразумевает под собой различного рода ошибки, связанные с появлением элементов уточняющей информации, с потерей ключевой информации, с потерей или появлением дополнительной и уточняющей информации и т.д. [5]

Например,

\section{Лиза час от часу более нравилась Алексею. [...] $\quad$ LizalikedAlexymoreandmoreeveryminute.. [...]}

При подробном рассмотрении примеров, логично предположить, что применении деформации привело к выбору в пользу приема модернизации.

Несмотря на то, что в современной технике перевода модернизация текста не признается, основываясь на простой логике равенства впечатлений: восприятие произведения современным читателем подлинника должно быть аналогично восприятию произведения современным читателем перевода. Применяя модернизацию ко всем случаям употребления просторечий, переводчик в очередной раз доказывает, что разговорно-диалектная окраска ИТ будет неизбежно потеряна и она сохраняет статус непереводимой.

Например, 


\begin{tabular}{|c|c|}
\hline $\begin{array}{c}\text { "Небось, милая,- сказал он Лизе, собака моя не } \\
\text { кусается". Лиза успела уже оправиться от } \\
\text { испугу и умела тотчас воспользоваться } \\
\text { обстоятельствами. "Да нет, барин, - сказала она, } \\
\text { притворяясь полуиспуганной, полузастенчивой, } \\
\text { - боюсь: она,вишь, такая злая; опять кинется""'Я } \\
\text { провожу тебя, если ты боишья, -сказал он ей, - } \\
\text { ты мне позволишь идти подле себя?" } \\
\end{array}$ & $\begin{array}{l}\text { “Don'tbeafraid,mydear,” hesaidtoLiza: } \\
\text { “mydogwon'teatyou. “Ohyeah, sir,” she said, } \\
\text { pretending partial shyness, "But I’m scared. See how } \\
\text { mean she is; she’s throwing herself at me again.” } \\
\text { "I’ll come with you if you're afraid,” he told her, } \\
\text { «Will you let me walk beside you?? }\end{array}$ \\
\hline $\begin{array}{c}\text { - "И ты не обманешьменя?" } \\
\text { - "Не обману". } \\
\text { - "Побожись". }\end{array}$ & $\begin{array}{l}\text { “You won’t trick me?” } \\
\text { “I won’t trick you.” } \\
\text { "Swear.” }\end{array}$ \\
\hline
\end{tabular}

Несмотря на то, что зачастую переводчики намеренно применяют прием стилизации, с целью создания временной дистанции, в рассматриваемом тексте перевода, переводчик полностью отказывается от этого и нейтрализует «крестьянское наречие».

Перевод художественных текстов по праву является одним из самых трудных видов переводческой деятельности. В первую очередь это объясняется тем, что каждое слово художественного текста обладает высокой смысловой нагрузкой. Переводчику приходится не просто механически переводить текст, а воссоздавать каждую строчку заново.

Сложность такого перевода обуславливается еще и временной привязкой текста оригинала, в следствие чего переводчик практически не способен передать некоторые архаизмы или реалии ИЯ.

Также трудность литературного перевода заключается в различном “видении мира” - специфическими для английского и русского языков способами его осознания и отражения. Две европейские культуры - английская и русская достаточно близки, но имеющиеся различия отнюдь не упрощают задачу литературного перевода.

На основании проведенного исследования можно сделать вывод, о том, что перевод художественного текста невозможен без потерь и различного рода деформаций. Однако, основная задача переводчика должна заключаться в минимизации случаев бессознательных трансформаций, поскольку они приводят к неполному или неправильному пониманию содержания произведения. Помимо этого, нельзя не согласиться с теоретиками перевода, которые отказываются 
признавать модернизацию текста верной переводческой стратегией, поскольку, применяя этот прием, переводчик лишает свой текст присущих оригиналу самобытности, «духа прошлого» и личностных особенностей героев произведения.

\section{Литература:}

1. Абакумов С. И. Из наблюдений над языком «Повестей Белкина» // «Стиль и язык А. С. Пушкина», М., 1937, с. 66-89.

2. Billings J. Tales of Belkin. NY, Brooklyn: Melville House. 2009. p. 83-108.

3. Пушкин A.C. Капитанская дочка. 1836. URL: http://rvb.ru/pushkin/01text/06prose/01prose/0869.htm

4. Гарбовский Н.К. Теория перевода. М.: Изд-во Моск. ун-та, 2004. 544 с. URL: http://www.studfiles.ru/preview/3537157/

5. Комиссаров В.Н, Теория перевода (Лингвистические аспекты). М.: Высш. шк., 1990. 253 с. 